

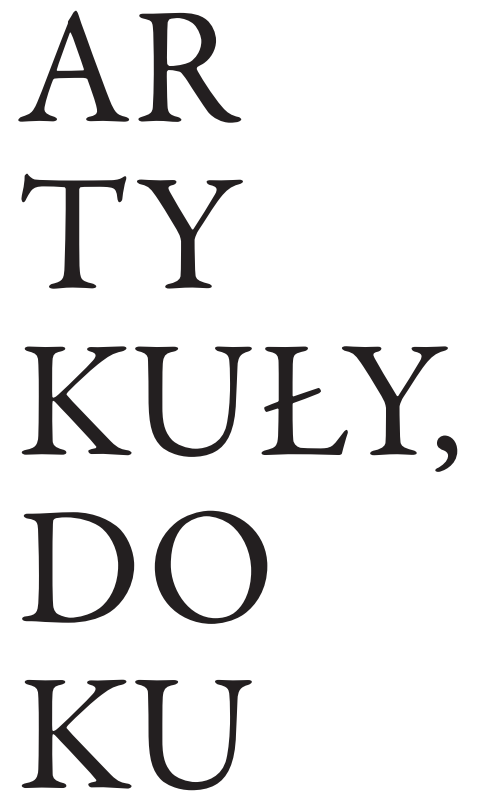

MEN

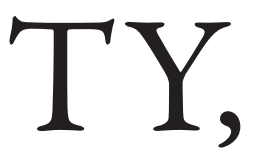

MANU

SKRYP

TY

Sztuka Edycji 1/2019

ISSN 2084-7963 (print)

ISSN 2391-7903 (online)

s. $163-176$
Mirosław Strzyżewski

\section{Nieznane archiwum rodzinne Mochnackich}

Losy dokumentów po Maurycym Mochnackim i innych członkach rodziny tak bardzo zasłużonej w naszych dziejach narodowych mają swój dalszy ciąg.

Śmierć Maurycego nastąpiła w Auxerre (20 grudnia 1834 roku), gdzie do ostatnich chwil życia pracował nad kolejnym tomem historii Powstania narodu polskiego w roku 1830 i 1831. Dopiero co skończył trzydzieści jeden lat. Miał dobrą opiekę francuskiego lekarza i życzliwego grona kilku rodaków, także przebywających wówczas na emigracji w mieście położonym w centralnej Francji. Do Auxerre przyjechał wraz z Antonim Walewskim. Oficjalnie dla podreperowania stanu zdrowia. Ale w rzeczywistości salwował się ucieczką z Paryża z powodów finansowych. Utrzymanie w stolicy Francji było znacznie droższe niż na prowincji. Uciekał też przed zgiełkiem wielkiego miasta i przed rodakami, którzy nie dawali mu spokoju. W Auxerre mieszkał w dzielnicy „de la Marine”, za katedrą, w pobliżu rzeki Yonne, przy ulicy, która dziś nosi nazwę rue des Vielles-Tanneries. Niedługo. Ledwo kilka tygodni. Sekcja zwłok wykazała, że przeszedł zawał serca, co było jedną z przyczyn szybko pogarszającego się stanu zdrowia. Raczej nie zmarł z powodu gruźlicy, jak to powiela literacka legenda (zob. il. 1-3). Ta nieuleczalna wówczas choroba była natomiast przyczyną także przedwczesnej śmierci w wieku dwudziestu siedmiu lat brata - Kamila Mochnackiego, zmarłego rok wcześniej w Hyères, na południu Francji. Bezpośredniej przyczyny zgonu Maurycego lekarze polscy upatrywali w „zapaleniu mózgu” i „anewryzmacie” (tzw. tętniak, czyli skrzep krwi na tętnicy szyjnej), co w dzisiejszej nomenklaturze medycznej odpowiadałoby raczej wylewowi krwi do mózgu; lekarze francuscy natomiast stwierdzili w oficjalnym akcie zgonu przechowywanym $\mathrm{w}$ archiwum merostwa w Auxerre ,anginę”. W liście do rodziców z 8 września 1833 roku, donosząc o zgonie młodszego brata Kamila, Maurycy oględnie wspomina i własną zapaść:

Wiedząc o każdym postępie choroby [Kamila], chciałem w lipcu pojechać, żeby przynajmniej ostatnie momenty z nim podzielić, aby na moim ręku 

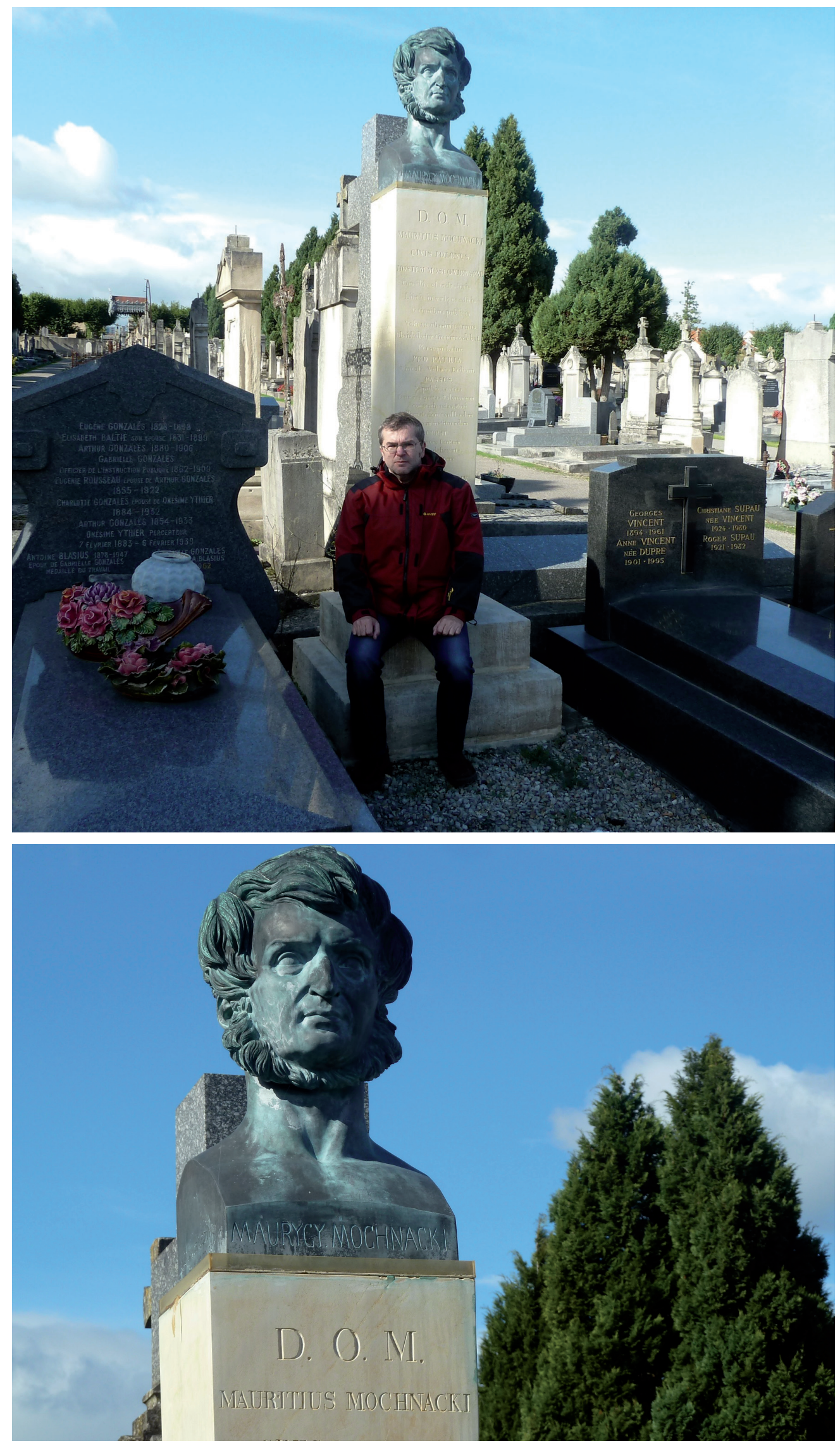

Il. 1-2. Grób Maurycego Mochnackiego w Auxerre
Bezpośredniej przyczyny zgonu Maurycego lekarze polscy upatrywali $\mathrm{w}$,zapaleniu mózgu" i „anewryzmacie” 


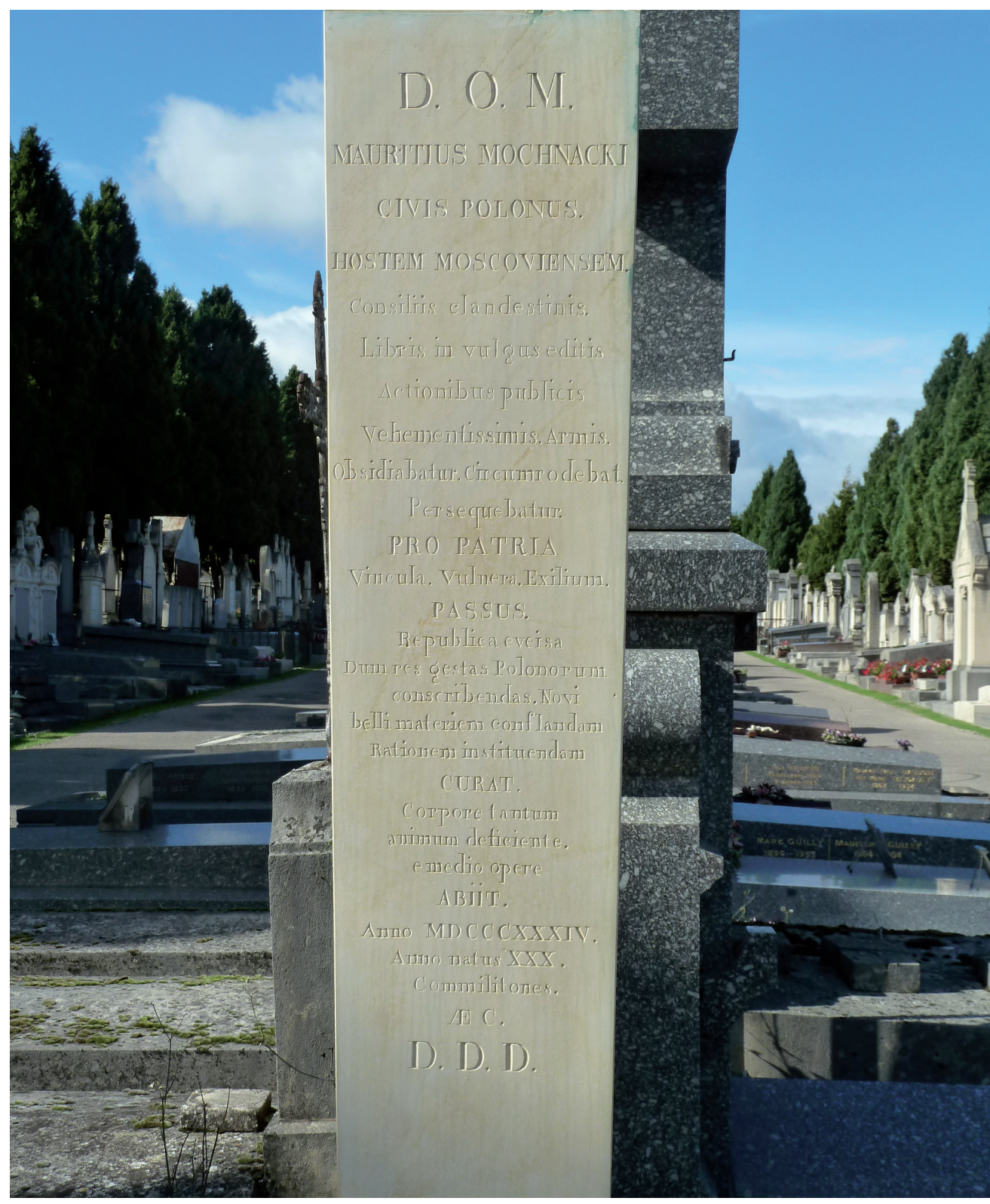

Il. 3. Inskrypcja nagrobna

skonał. Gdy w tym z wielkiego żalu padłem na łóżko i dostałem gwałtowne kłucia w sercu, żem po wielkich tylko upuszczeniach krwi mógł przyjść do siebie¹.

W rok później ponownie informuje rodziców:

$\mathrm{Z}$ dnia trzeciego na czwarty sierpnia dostałem gwałtownej gorączki, miałem kłucie w boku i bicie krwi do serca jak przeszłego roku. Widząc, że polscy doktorowie

Dzieła Maurycego Mochnackiego, wydanie jedynie prawne, ogłoszone z wiedzą matki autora, t. 1: Listy Maurycego Mochnackiego i brata jego Kamila, wyszłych z wojskiem polskim do Francji w roku 1831, pisane z Paryża, Metz i Avignon do rodziców swoich w Galicji, Poznań 1863, s. 227. 
nie mogą mi dać rady, wezwałem jednego z najsławniejszych lekarzy, pana Riccard, który natychmiast przybył i oświadczył, że mnie wykuruje bez żadnej zapłaty.

[...] Kazał on mi przystawić 100 pijawek we trzech dniach, leżeć w łóżku i jeść tylko pół funta winogron na dzień, pić filiżankę lekkiego bulionu. Tym sposobem żyłem dni dwadzieścia... ${ }^{2}$

Maurycy - w przeciwieństwie do brata Kamila - nie należał bynajmniej do młodzieńców o wąttej kondycji fizycznej. Matka, Maria Mochnacka z Pagowskich, we wspomnieniach załączonych do wydanej korespondencji pisała o harcie ducha i ciała Maurycego, „który był tak zbudowany dobrze. Młody, silny, bez najmniejszych defektów, młodość jego tak zakonserwowana; jednakże zgryzoty potrafiły rozprząc ten organizm pełen życia”’.

Był znakomitym pisarzem i publicystą, błyskotliwym krytykiem literackim, muzycznym, teatralnym, zafascynowany romantyzmem propagował nowoczesne idee i nową estetykę, ale w dużej mierze zgubiła go polityka ${ }^{4}$. Dla pisarza działalność polityczna staje się często utrapieniem i balastem. Tak było i w tym przypadku. Zarówno w czasie powstania listopadowego, jak i na emigracji poświęcał się jej bez reszty. Żył w ciągłym pośpiechu, napięciu, na granicy wytrzymałości psychicznej i fizycznej, ciężko ranny w bitwie pod Ostrołęką, schorowany, jednak zawsze pełen zapału, skory do polemik, z mnóstwem idei i pomysłami mającymi przynieść Polsce wolność. Romantyk. Żył krótko, lecz intensywnie. I wiele po sobie zostawit.

Niemal natychmiast po śmierci Maurycego rozpoczął się nieprzyzwoity wyścig. Emigracyjni politycy, a raczej rozmaitej maści politykierzy, koniecznie chcieli uzyskać dostęp do cennych materiałów. Było ich sporo. Część została komisyjnie opieczętowana i oddana w depozyt do paryskiego Towarzystwa Historyczno-Literackiego. W Bibliotece Polskiej w Paryżu przechowywany jest zbiór „Dokumenty rozmaite dotyczące depozytu Maurycego Mochnackiego 1835-1838”, z którego można dowiedzieć się o pierwotnej zawartości tylko tej części fascykułów, które zostały komisyjnie opieczętowane. To jakby inwentarz tego, co po śp. Maurycym Mochnackim pozostało w Auxerre i co zdeponowano następnie w Paryżu. Ale zawartość paczek zniknęła. Wiemy, co w nich było, jednak ślad po większości spuścizny, przejrzanej i opieczętowanej przez komisję, urywa się w 1838 roku. Można powiedzieć, że zawartość paczek zdeponowanych w Towarzystwie była bardzo bogata. Co z tego zespołu archiwalnego dotarło do rodziny, co uległo rozproszeniu na emigracji, a jaka część ostatecznie dotarła do bibliotek - bardzo trudno precyzyjnie określić. W Bibliotece Polskiej przechowywany jest egzemplarz książki Richarda Ottona Spaziera Geschichte des polnischen Volkes und seines Feldzuges im Jahre 1831. Z książki tej korzystał na pewno Maurycy Mochnacki w trakcie prac nad swoim dziełem o powstaniu i wojnie z Rosją. Na marginesach zachowały się odręczne notatki ręki Mochnackiego, które mają charakter ironicznych i krytycznych komentarzy. Być może jest to jedyny materialny ślad depozytu. Wiemy, że pewne rękopisy Mochnackiego pozostawały w Bibliotece Ordynacji Zamoyskich i spłonęły w Warszawie w 1944 roku.

${ }^{2}$ Ibidem, s. 255.

${ }^{3}$ Ibidem, s. 161

${ }^{4} Z$ wielu interesujących prac poświęconych poglądom i biografii politycznej Maurycego Mochnackiego warto wskazać choćby następujące książki: B. Łagowski, Filozofia polityczna Maurycego Mochnackiego, Kraków 1981; S. Pieróg, Maurycy Mochnacki. Studium romantycznej świadomości, Warszawa 1982; Z. Przychodniak, Walka o rząd dusz. Studia o literaturze i polityce Wielkiej Emigracji, Poznań 2001. 
Inne znalazły się w zbiorach Biblioteki Akademii Umiejętności w Krakowie (część korespondencji). Niektóre pozostają w Bibliotece Czartoryskich. Warto podkreślić, że w Polsce znalazły się dokumenty, choćby korespondencja, które nie są wymienione w owym ,inwentarzu”. Pochodziły najprawdopodobniej ze zbiorów rodzinnych i zostały następnie sprzedane lub podarowane. Nie znamy losów korespondencji rodziców i krewnych, przysyłanej z Galicji do Francji. Prawdopodobnie zostały po śmierci Maurycego zwrócone rodzicom, ale nie natrafiłem na ich ślad. Nie mówi się też o nich przy okazji spisywania pozostałości po zmarłym. Zbigniew Przychodniak i Krzysztof Trybuś opublikowali całe komisyjne dossier ${ }^{5}$, znane także niżej podpisanemu ${ }^{6}$, choć kilka ustaleń trzeba będzie zweryfikować w świetle odnalezionych obecnie nowych dokumentów rodzinnych. Sporo materiałów jeszcze przed zinwentaryzowaniem zostało rozproszonych, by nie rzec: rozkradzionych, o czym pośrednio można wywnioskować z zachowanej korespondencji emigrantów (Antoni Walewski, Wincenty Chełmicki, Janusz Woronicz, Leonard Chodźko). Na pewno duża część (nieskatalogowana) została przesłana rodzinie.

Osobliwy obraz wyłania się z trzech protokołów Jełowickiego. Oto emigranci polscy - Barzykowski, Morozewicz, Wołowski, major Dembowski - w mieszkaniu Jełowickiego późnymi zimowymi wieczorami sortują i opieczętowują rękopisy, książki, listy, zapiski pozostawione przez Mochnackiego. Członkowie tej komisji wzajemnie się kontroluja, przeliczają materiały po kilka razy, na czas przerwy w pracy zamykają je w szafie, powierzając klucz od niej Wołowskiemu?

Mimo tych środków bezpieczeństwa owa „masa upadłościowa” tak skrupulatnie odnotowywana i katalogowana - po prostu znikła. Przed wielu laty w Bibliotece Polskiej zaintrygował mnie pewien zapis. Na karcie tytułowej zbioru „Dokumenty rozmaite dotyczące depozytu Maurycego Mochnackiego 1835-1838” widnieje wyraźnie położona w nawiasie informacja tej samej ręki, która wpisywała przytoczony wyżej nagłówek: „Korespondencja, sprawozdania komisji - rękopisy zeszyte w zeszyt”. Niestety, nie udało mi się ustalić daty sporządzenia owej karty tytułowej. Przecież zapis archiwalny nie pochodził od Aleksandra Jełowickiego nadzorującego prace komisji, ale powstał znacznie później. Wiedziałbym wówczas, w jakim okresie przynajmniej część z zaginionych materiałów była jeszcze dostępna w Bibliotece. W przeciwnym razie należałoby się spodziewać adnotacji o zaginięciu depozytu, o którym mowa w dokumentach. Spekuluję, rzecz jasna. Próbowałem też przeszukiwać w archiwach pozostałości po osobach, które bezpośrednio były zaangażowane w prace komisji. Nie przyniosło to wymiernych rezultatów. Bez wątpienia losy tej spuścizny są wyjątkowo zagmatwane, a przez to fascynujące. I - co istotne - ciągle dopisywany jest ich nowy rozdział. Nadal tedy aktualne jest zdanie Krzysztofa Trybusia: „Rękopiśmienna spuścizna Maurycego Mochnackiego

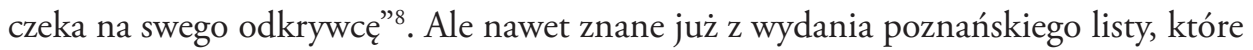
szczęśliwie zachowały się również w rękopisach, wymagają ponownego opracowania. Kolaudacja autografów i pierwodruków doprowadziła do zaskakujących odkryć. Otóż

${ }^{5}$ Z. Przychodniak, K. Trybuś, O losach spuścizny rękopiśmiennej po Maurycym Mochnackim w świetle dokumentów Towarzystwa Literackiego w Paryżu z lat 1835-1838, w: Akta Towarzystwa Historyczno-Literackiego w Paryżu, t. 3, Paryż 1996, s. 73-97.

${ }^{6}$ M. Strzyżewski, Podwóina śmierć Maurycego Mochnackiego, w: Polonistyka toruńska Uniwersytetowi w 50. rocznice utworzenia UMK. Literaturoznawstwo, pod red. J. Kryszaka, Toruń 1996, s. 95-105.

${ }^{7}$ K. Trybuś, Tajemnicze losy spuścizny po Mochnackim, w: Nasze pojedynki o romantyzm, pod red. D. Siwickiej i M. Bieńczyka, Warszawa 1995, s. 264

${ }^{8}$ bbidem, s. 261. 
niemal wszystkie teksty w wydaniu poznańskim zostały poważnie zniekształcone wskutek cenzury politycznej i rodzinnej. Nadto zostały wydane bardzo niestarannie, z wieloma błędami. Zachowane autografy w zestawieniu z pierwodrukami wykazują sporo różnic m.in. o charakterze stylistyczno-językowym i redakcyjnym. Prawdopodobnie rodzinną cenzurę obyczajową zastosowała matka, która przygotowywała to wydanie, aby w możliwie dobrym świetle ukazać perypetie synów, zwłaszcza Maurycego, ale niewykluczona jest też ingerencja cenzury pruskiej w polityczną materię listów oraz wydawcy9 Autografy umożliwiły przywrócenie pierwotnej stylistyki korespondencji, przy czym zmian o charakterze językowym i redakcyjnym jest bardzo dużo. Dość powiedzieć, że niemal każde zdanie w cytowanej tu już wcześniej korespondencji wydanej nakładem Konstantego Żupańskiego nosi znamiona mniejszych lub poważniejszych ingerencji o rozmaitej proweniencji. Wydanie poznańskie stanowi przykład wyjątkowo niestarannego obchodzenia się z podstawą tekstową, uwzględniając nawet ówczesne obyczaje edytorskie w tym zakresie. Tym samym nawet znane już rękopisy odkrywamy dziś niejako na nowo, przywracając im właściwą, poprawną postać. Jednakowoż zapowiadane prace nad nową krytyczną edycją listów chwilowo się zatrzymały. A powodem tego jest szczególne odkrycie.

Powtórzmy: dokumenty z teczki zbierającej protokoły komisji opisującej zbiór materiałów, jakie pozostały po śmierci Maurycego, wskazują na istnienie wielu ciekawych rękopisów po zmarłym pisarzu i polityku, ale stosunkowo szybko ślad po nich zaginął. Prawdopodobnie pewna mała część z tej spuścizny odnalazła się szczęśliwie u spadkobierców rodziny. Pani Marta Ławacz, która odziedziczyła rodzinne archiwum Mochnackich, udostępniła mi swoje zbiory do opracowania naukowego. Sytuacja była dla mnie zaskoczeniem i spełnieniem po części marzeń o odnalezieniu nieznanych dokumentów Maurycego, któremu poświęciłem wcześniej sporo prac naukowych. Przygotowywałem właśnie krytyczne wydanie korespondencji braci Kamila i Maurycego Mochnackich oraz zaprzyjaźnionego z nimi Michała Podczaszyńskiego, ale prace po tym odkryciu należało przerwać, by włączyć do monografii edytorskiej nowe dokumenty. Wydawnictwo Naukowe UMK i niżej podpisany dzięki pani Marcie Ławacz nabyli prawa do opracowania i upowszechnienia nieznanego dotąd archiwum rodzinnego Mochnackich. Na toruńskiej konferencji naukowej „Intymistyka a edytorstwo” 15 listopada 2018 roku wspólnie z panią Martą przedstawiliśmy w ogólnym zarysie projekt edycji oraz zawartość archiwum (zob. il. 4). Współpraca przebiega znakomicie i zapewne w ciągu kilku lat zostanie spuentowana w postaci edycji książkowej oraz nieco później elektronicznej.

Do ujawnienia nieznanego archiwum rodzinnego doszło przypadkowo, choć zapewne tak miało się właśnie stać. Pani dr Agnieszka Markuszewska, odpowiedzialna w przygotowywanej edycji korespondencji za stronę redakcyjną i opracowanie edytorskie, opublikowała w internecie krótką zapowiedź tego właśnie wydania. Informacja drogą elektroniczną dotarła do pani Marty Ławacz, która już od pewnego czasu poszukiwała

\author{
Nawet znane \\ już rękopisy \\ odkrywamy dziś \\ niejako na nowo, \\ przywracając \\ im właściwą, \\ poprawną postać
}

${ }^{9}$ A. Markuszewska, Ingerencje w pierwodruk edycji listów Kamila i Maurycego Mochnackich, w: Z warsztatu edytora dzieł romantyków, pod red. M. Bizior-Dombrowskiej i M. Lutomierskiego, Toruń 2008. 
badaczy, którzy pomogliby jej w opracowaniu zbiorów, a może nawet w ich wydaniu. $\mathrm{Na}$ adres e-mailowy pani doktor dotarł krótki list od Marty Ławacz z informacją, że jest w posiadaniu rodzinnego archiwum Mochnackich, w którym są również listy. E-mail zawierający także numer telefonu został natychmiast mi przekazany. Doprawdy, trudno mi było uwierzyć w treść listu. Może to jakaś pomyłka lub żart? Zadzwoniłem niemal natychmiast. Wszystko zostało potwierdzone. I w ten oto sposób rozpoczęła się nasza współpraca. Pani Marta Ławacz opisuje dzieje owego archiwum domowego pięknie, choć lapidarnie:

[...] najtrudniej opisywać proste historie. Historie toczące się z dnia na dzień, losy majątku przechodzącego z ojca na syna. Listy pisane przez Kamila i Maurycego we Francji docierały do rodziny pomimo tułaczki ich adresatów. Rodzina uciekła z terenów będących pod jurysdykcją Rosjan po klęsce powstania listopadowego, zapewne zabierając ze sobą również rodzinne dokumenty. Maria Pągowska razem z córkami spotkały Bazylego i Tymoleona, którzy do tej pory również przechodzili swoje własne odyseje. Dokładnie opisuje to Maria Pągowska w suplemencie do wydanej korespondencji synów. We Lwowie dociera do rodziny najpierw informacja o śmierci Kamila, a potem Maurycego.

Rodzina osiadła w Galicji, gdzie po kilku latach nabyła majątek. Życie zaczęło toczyć się swoim normalnym, powolnym trybem. Zawierano małżeństwa, rodziły się dzieci... Tymoleon miał kilkoro dzieci z dwóch związków. Pierworodny Seweryn, z małżeństwa z ukochaną żoną Zosią z Pągowskich, umarł młodo, osierocając kilkoro dzieci (w tym moją prababkę Sewerynę). Po jego śmierci naturalnym dziedzicem powinien zostać młodszy brat Karol. Sprawa nie była jednak tak prosta. Karol był „czarną owcą" rodziny i morfinistą, „wpuszczającym w żyły” kolejne kosztowności, lasy, majątki. Ojciec pisze o nim: „Łatwowierny i uważając każdym uczciwego człowieka, jakim sam jest, wszedł w towarzystwa, w których pewnie zbudować się nie mógł". Poza tym Karol „przyswoił sobie różne nałogi”. Oczywiste jest, że nie mógł zostać dziedzicem ro-

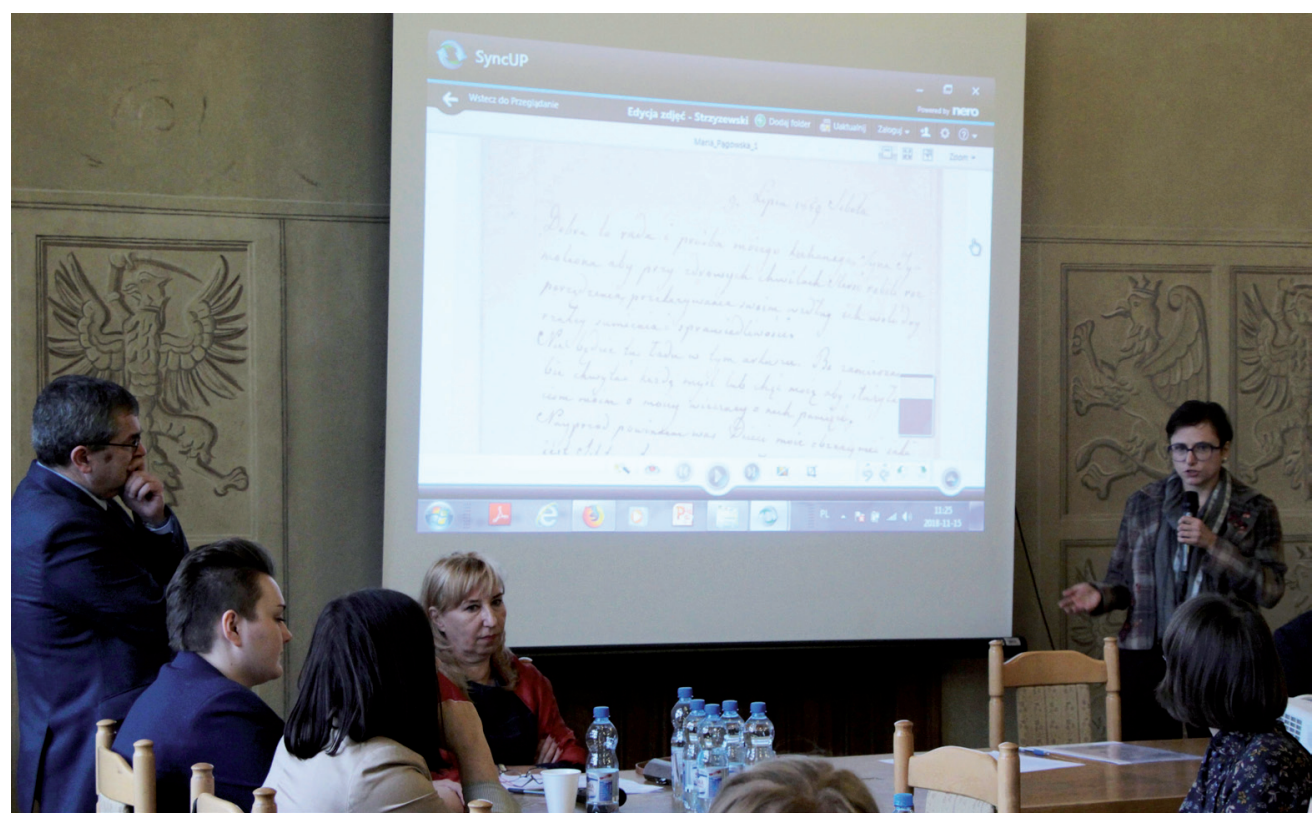

Il. 4. Wystąpienie Marty Ławacz na konferencji w Toruniu 
dzinnego majątku. Rad nierad, Karol zrezygnował z pretensji do majątku, w kolejnych swoich testamentach prosił ojca o wybaczenie i spłaty kolejnych długów.

Dziedziczką majątku Tyśmieniczany została wspomniana wcześniej córka Seweryna, moja prababka Seweryna. W testamentach niestety brak informacji o rodzinnych dokumentach. Faktem jest, że znalazły się one w całości lub może w części w posiadaniu Seweryny, a od niej już prosta droga do mnie. Seweryna miała jedynego syna Włodzimierza z małżeństwa z moim pradziadkiem, Władysławem Jungiem, późniejszym generałem Wojska Polskiego. Po odzyskaniu niepodległości pradziadkowie mieszkali w Krakowie. Wojna zastała ich, gdy byli na wakacjach u znajomych pod Lwowem. Pradziadek chciał dotrzeć przez zieloną granicę do Krakowa, lecz niestety wpadł w ręce Rosjan. Wmówił im, że jest emerytowanym nauczycielem. W jaki sposób znany wojskowy, zasłużony w wojnie 1920 roku, to zrobił, pozostaje dla mnie zagadką. Rosjanie wypuścili pradziadka z więzienia w stanie agonalnym. Umarł we Lwowie, a moja prababcia Seweryna została wywieziona do Kazachstanu, skąd wyszła z Armią Andersa, i umarła w Egipcie w 1945 roku. Wszystkie dokumenty przetrwały wojnę w Krakowie. Mój dziadek - Włodzimierz Junk-Mochnacki - wrócił po wojnie z oflagu (Murnau) i zamieszkał w Krakowie. Wszystkie dokumenty po rodzicach przechowały się u dziadka. Pod koniec lat siedemdziesiątych, mógł to być siedemdziesiąty ósmy lub dziewiąty rok, w piękny lipcowy dzień dziadek przyjechał do nas swoim stylowym, srebrnym Volkswagenem garbusem rocznik' 53 i zażądał wyniesienia bagażu. W jednej z walizek było archiwum rodzinne. Od tej pory dokumenty są w naszym posiadaniu ${ }^{10}$.

Opisana przez Martę Ławacz wędrówka rodzinnych dokumentów, szczęśliwie zachowanych, i rola w niej dziadków, którzy młodemu pokoleniu przekazują spuściznę po przodkach, stanowi przykład świadomej dbałości i troski o zachowanie pamięci rodzinnej, a tym samym pamięci zbiorowej. Dziadkowie przekazujący wnukom cenną spuściznę wykonują ważki gest zaufania, wierząc, że dokumenty ocaleją pod opieką młodszego pokolenia. Sam w podobny sposób odziedziczyłem archiwum rodzinne po dziadkach od strony matki. Częściej jednak archiwa u nas płonęły, zarówno w domach prywatnych, jak i w bibliotekach, tudzież były konfiskowane przez rozmaite organa władzy, niszczone przez okupantów czy zaborców i pożogi wojenne. Dlatego tak ważne jest ocalenie tego wszystkiego, co pozostało z przeszłości, a znajduje się jeszcze w rękach prywatnych.

W archiwum Mochnackich pani Marty, ocalałym po prababce Sewerynie z domu Pągowskich, przynajmniej część dokumentów istotna jest dla naszej wiedzy o Maurycym i Kamilu Mochnackim, powstańcach i politykach z okresu wojny polsko-rosyjskiej 1831 roku, pozostałe stanowią ważne źródło do odtworzenia dalszych losów rodziny Mochnackich, które były również zajmujące. Wyjątkową rolę odegrała tu matka Maurycego, Kamila, Tymoleona, Klementyny i Olimpii - Maria z Pagowskich (zm. najprawdopodobniej w 1867 roku), która na początku XIX wieku wyszła za mąż za Bazylego Mochnackiego (1777-1844), znanego prawnika, powstańca kościuszkowskiego, członka Rządu Narodowego podczas powstania listopadowego. Od Marii z Pagowskich Mochnackiej wszystko się zaczęło. To właśnie matka Maurycego i Kamila upowszechniła ich listy (Poznań 1863), dbała o dobre imię rodziny, odziedziczyła też zapewne sporą część spuścizny po zmarłych synach. A po niej Seweryna i następne po-

${ }^{10}$ Referat Marty Ławacz; w zbiorach autora artykułu. 
kolenia. Inną część dokumentów rodzinnych prawdopodobnie przejął najmłodszy z braci - Tymoleon (1811-1889), dziedzic majątków Czortowiec w powiecie kołomyskim, Zabereże i Tyśmieniczany w powiecie stanisławowskim (Ukraina). Mam nadzieję, że zachowała się gdzieś i ta część spuścizny rodziny Mochnackich i może kiedyś ujrzy światło dzienne. Choć z drugiej strony można dostrzec, że w archiwum po Marii z Pągowskich znajdują się też dokumenty Tymoleona, co może dowodzić, że jego rodzinne pamiątki znalazły się w posiadaniu matki i jej bezpośrednich spadkobierców.

Archiwum rodzinne odziedziczone przez Martę Ławacz zawiera korespondencję, dokumenty, notatki, numery prasy, wspomnienia oraz testamenty (zob. il. 5-7). Wszystkie jednostki archiwalne dotyczą bezpośrednio rodziny Mochnackich, nie były wcześniej znane w całości (z wyjątkiem fragmentów z prasy), stanowią cenne źródło do dziejów rodu, dokumentują życie codzienne, uzupełniają także w znaczący sposób wiedzę o ostatnim okresie życia Kamila i Maurycego Mochnackich. Niektóre dokumenty są w złym stanie i są mało czytelne, będą trudne do odtworzenia. Inne, zwłaszcza sygnowane przez Marię Mochnacką, zachowały się w dobrym stanie. Bardzo cenne są zwłaszcza listy Antoniego Walewskiego i Stefana Dembowskiego przysłane do rodziców po śmierci Maurycego. Znane były dotąd tylko we fragmentach i w parafrazach matki z edycji poznańskiej. Istotne są dla odtworzenia losów pośmiertnych spuścizny po Maurycym Mochnackim. Drobne dokumenty Kamila Mochnackiego z okresu przed powstaniem listopadowym były chyba w domu rodzinnym, nie ma dowodów czy choćby wskazówek, że odesłano je z Francji. Maria Mochnacka potwierdza swój talent literacki fragmentami zachowanych wspomnień. W testamentach nie wspomina się o ewentualnym dziedziczeniu dokumentów po Bazylim, Maurycym czy Kamilu. Warto zauważyć, że Tymoleon, najmłodszy syn Bazylego i Marii

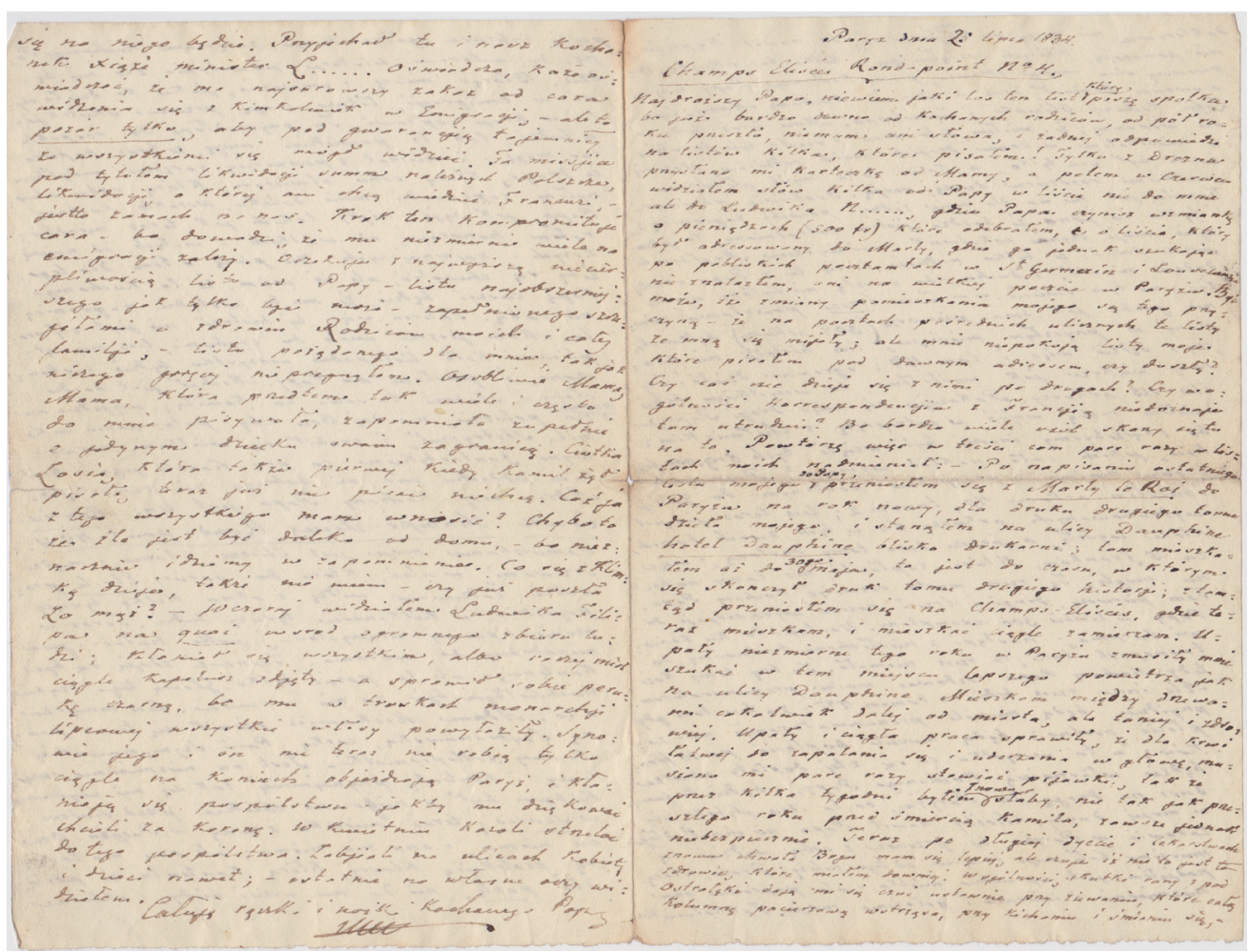

Il. 5. List Maurycego Mochnackiego do rodziców z 28 lipca 1834 roku 
z Pągowskich, ochrzcił swojego pierworodnego syna imieniem zmarłego we Francji brata. W rodzinie Mochnackich było więc dwóch Kamilów.

Poniżej przedstawiam roboczy rejestr jednostek archiwalnych, który nie jest jeszcze dokładnie i w pełni opracowany, stąd też mogą w nim wystąpić spore zmiany w dalszej fazie opracowywania zbioru. Najważniejsze dokumenty będą stopniowo publikowane, a także włączone w formie specjalnego aneksu do przygotowywanej nowej edycji korespondencji braci Mochnackich.

\section{Archiwum rodziny Mochnackich odziedziczone przez Martę Ławacz}

X 1809 - krótki list pisany po francusku, słabo czytelny, prawdopodobnie Bazylego Mochnackiego, datowany w Wiedniu

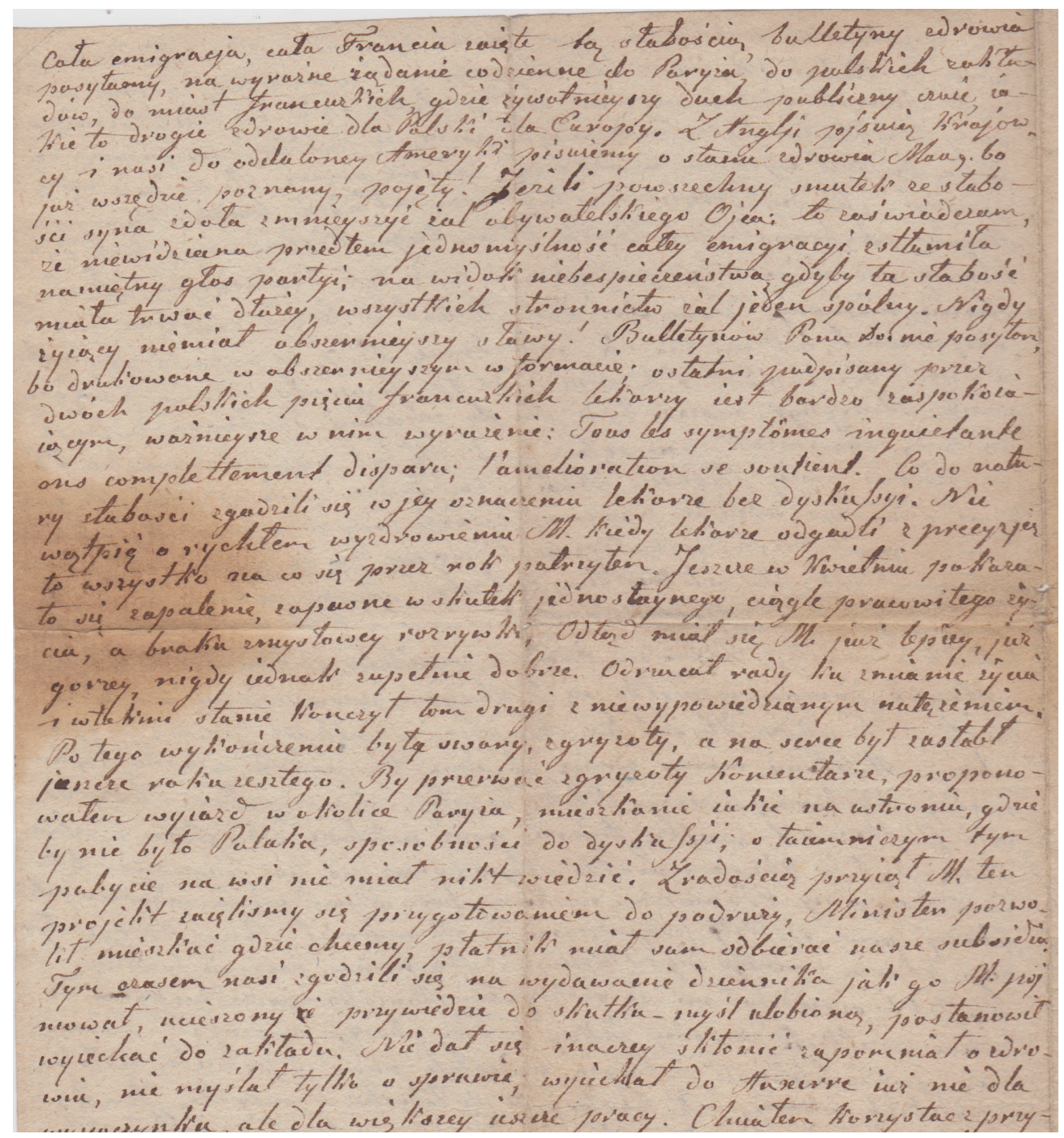

Il. 6. List Antoniego Walewskiego i Stefana Dembowskiego do Mochnackich

Sztuka Edycji 1/2019 
Maria Mochnacka potwierdza swój talent literacki fragmentami zachowanych wspomnień

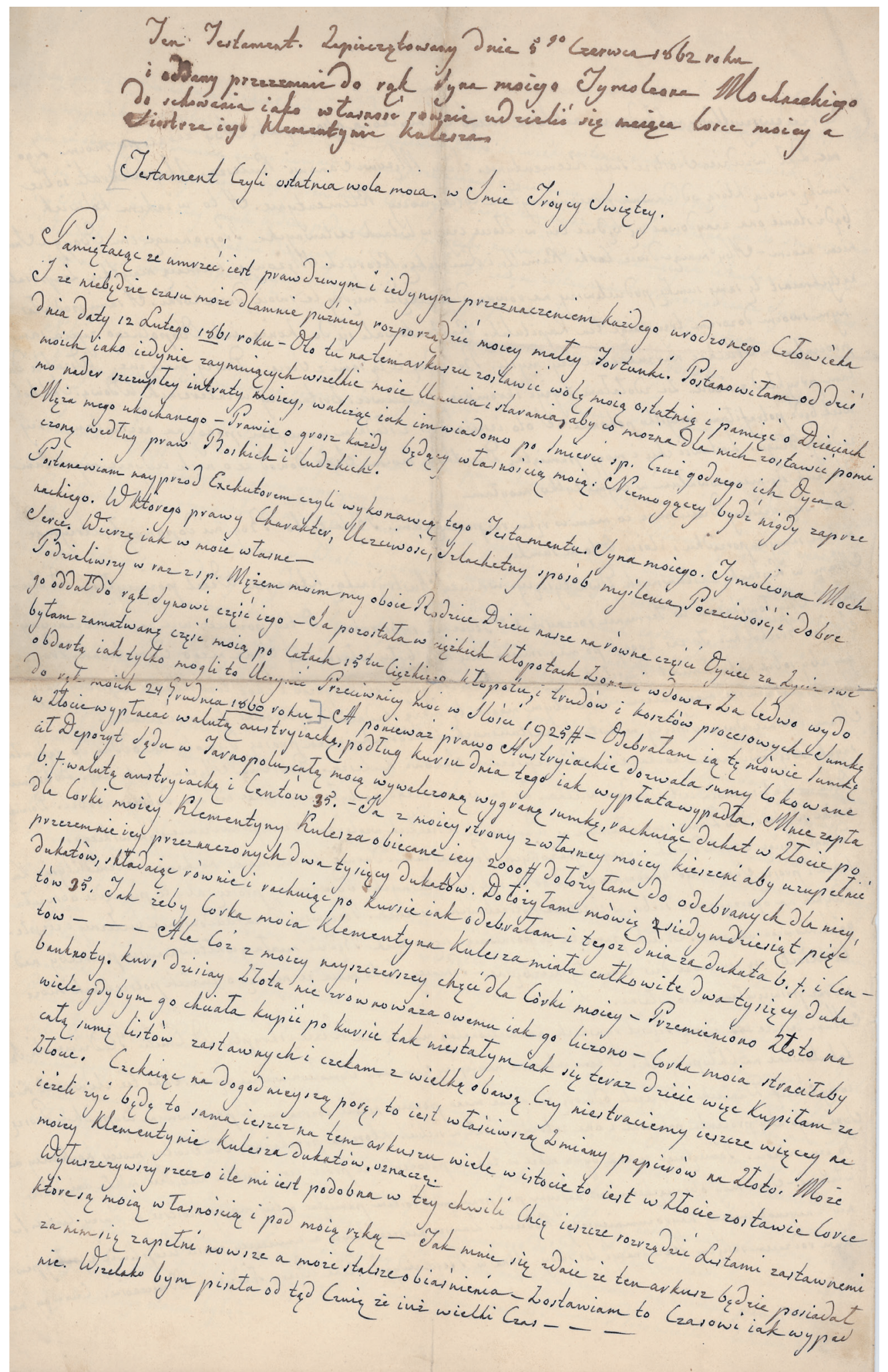

Il. 7. Testament Marii Mochnackiej 
13 VI 1825 - „My Aleksander...” - nadanie orderu Świętego Stanisława III klasy Bazylemu Mochnackiemu

"Gazeta Korrespondenta Warszawskiego i Zagranicznego" - dwa numery pisma z 30 VII 1825 i z 1 VIII 1825 roku

28 VIII 1826 - „Warunki odjeżdżających na urlop Kadetów” - z tyłu notatka: „syn mój Tymoleon ................ stosował się do powyższych warunków" i podpis: Mochnacki Bazyli

11 IV 1827 - dokument urlopowy Tymoleona Mochnackiego z Korpusu Kadetów w Kaliszu

4 III 1830 - bilet wyjścia z Koszar Aleksandryjskich do miasta Warszawy (dotyczy prawdopodobnie Kamila)

23 IX 1830 (?) Olkusz - zaświadczenie dotyczące Józefa Teofila (?) Boreckiego

„Polak Sumienny” - pismo czasowe z 4 XII 1830 roku

„Kurier Warszawski” - numery z 11 II 1831, 22 II 1831, 23 II 1831 roku

18 III 1831, 10 rano - kartka, Maurycy pisze do brata Kamila

21 IV 183[1] - „Kommissya Województwa Kaliskiego...” - polecenie podstawienia podwody dla pary konnej [K.] Mochnackiego, porucznika pułku

„Kurier Polski” - numer z 20 V 1831 roku

25 IX 1831 w obozie pod Olkuszem - dotyczy Teofila Boreckiego

16 X 1831 - stan służby wojskowej Teofila Boreckiego i uwolnienie od służby, podpis: szef sztabu Pułkownik

22 XII 1831 - „Komisarz wojewódzki w obwód Mławski delegowany...”, czasowe pozwolenie pobytu dla Tymoleona Mochnackiego

19 II 1834 - list Bazylego Mochnackiego do Tymoleona

25 VII 1834 - list Maurycego Mochnackiego do ojca, datowany w Paryżu, oraz odpis tego listu

2 IX 1834 - list Maurycego Mochnackiego do rodziców oraz odpis tego listu

20 XII 1834 - list Antoniego Walewskiego do rodziców Maurycego, datowany w Auxerre, oraz odpis tego listu 
28 II 1835 - list od Antoniego Walewskiego i majora Stefana Dembowskiego do rodziców Maurycego, datowany w Auxerre

17 VI 1836 - list Bazylego Mochnackiego do komornika

6 II 1837 - list Zofii Mochnackiej do męża (Tymoleona)

28 II 1838 - list prawdopodobnie od Tymoleona i Zofii do syna (Seweryna)

2 IX 1838 - list datowany w Montpellier do Józefa Boreckiego, podpis nadawcy nieczytelny

11 XI 1840 - list datowany w Trieście, w języku włoskim, podpis Elisa Addio (?)

15 V 1851 - życzenia imieninowe Kamila Mochnackiego dla matki Zofii

Archiwum

rodzinne zawiera korespondencję, dokumenty, notatki, numery prasy, wspomnienia oraz testamenty
2 III 1853 - list Kamila Mochnackiego (wnuka Marii) do rodziców (Tymoleona i Zofii)

4 II 1858 - list Kamila Mochnackiego do rodziców (Tymoleona i Zofii)

8 V 1859 - list Kamila Mochnackiego do rodziców, datowany w Weronie

23 V 1859 - list Kamila Mochnackiego do rodziców, datowany w Weronie

3 VII 1859 - list Kamila Mochnackiego do rodziców

[b.d.] - osiem listów Kamila Mochnackiego do rodziców z tego samego okresu

18 VI 1860 - „Wielmożnemu Tymoleonowi Mochnackiemu, właścicielowi dóbr Tyśmieniczany i Zabereże w Stanisławowie...", kontrakt w sprawie nabycia parceli

13 V 1862 - list Józefa Mochnackiego (kuzyna) do Marii Mochnackiej

15 V 1862 - list Marii Mochnackiej do Zosi

22 IX 1865 - list Marii Mochnackiej do Tymoleona

4 X 1865 - list Marii Mochnackiej do syna Tymoleona i jego żony Zosi

11 V 1866 - list Marii Mochnackiej do synowej Zofii

14 V 1866 - list Seweryna (wnuka Marii Mochnackiej) do rodziców (Tymoleona i Zofii)

30 IV 1867 - list Marii Mochnackiej do wnuka Karola

3 X 1868 - list rozpoczynający się od słów: „Drogi wujaszku i Malwinko” (?) 
IV 1869 - list w języku francuskim kuzyna A. Pągowskiego (adresat nieznany)

2 IV 1869 - list datowany we Lwowie rozpoczynający się od słów: „Kochany bracie...”, bez podpisu

22 XI [?] - list Józefa Boreckiego rozpoczynający się od słów „Zacny i drogi kolego”, adresat nieznany

23 I [?] - list Kamila Mochnackiego (wnuka Marii) do rodziców (Tymoleona i Zofii)

[b.d.] - list Brata Polaka (?) do Siostry Polki (?)

[b.d.] - list Zofii do Tymoleona

[b.d.] - list Zofii do cioci (?), datowany w Görbersdorf

[b.d.] - list do Zofii Pąowskiej w Czortowcu (prawdopodobnie od Marii Mochnackiej)

1859-1866 - Wspomnienia Marii z Pągowskich Mochnackiej dla rodziny, luźne kartki datowane w latach 1859-1866

1866 (?) - testament Marii Pągowskiej (b.d., prawdopodobnie 1866 rok)

1889 (?) - testament Tymoleona Mochnackiego (b.d., prawdopodobnie 1889 rok)

Key Words: Maurycy Mochnacki, Kamil Mochnacki, Maria Mochnacka of the Pąowski family, Marta Ławacz, family archives, memoirs, correspondence, November Uprising

Abstract: The archives of Mochnacki family inherited by Marta Ławacz includes correspondence, documents, notes, newspapers, memoirs and wills. All archival items directly concern the Mochnacki family, have not been previously known as a whole (except for the fragments from press), constitute a valuable source on the family's history, document daily life, as well as significantly supplement the knowledge on the final years in the lives of Kamil and Maurycy Mochnacki. Some documents are in bad condition and hardly readable, which will make them hard to recreate. Others, however, especially the ones signed by Maria Mochnacka, have survived well-preserved. Especially valuable items are the letters by Antoni Walewski and Stefan Dembowski, sent to their parents after Maurycy's death. The article presents a registry of archival units, which has not yet been carefully and fully studied, thus changes may appear at the further stages of its processing. 